\title{
IDENTIFIKASI KEBIMBANGAN TOKOH HASAN DALAM ROMAN ATHEIS KARYA ACHDIAT KARTA MIHARDJA
}

\section{(HESITATION IDENTIFICATION OF THE FIGURE OF HASAN IN “ATHEIS” NOVEL OF ACHDIAT KARTA MIHARDJA)}

\author{
Syaiful Bahri \\ Kantor Bahasa Provinsi Nusa Tenggara Barat \\ Jalan dr.Sujono, Kelurahan Jempong Baru, Sekarbela, Mataram, NTB, Indonesia \\ Pos-el: sbkailani@gmail.com
}

Diterima: 28 September 2013; Direvisi: 30 Oktober 2013; Disetujui: 1 November 2013

\begin{abstract}
The figure of Hasan was in the midst of the new and the old world. In other words, Hasan was in the world of "between", between the old and new world. That position made Hasan went to a period of indecision. The indecision was unfolded by using psychoanalysis of personality structural identification from Sigmund Freud. The identification was focused more to some instincts found in the area of id. The tenderness, appreciation, and freedom instincts which were going to be realized were collided by considerations existed in the area of ego and superego. The considerations showed that the actualization of instincts could not be realized in the old world, however they reappeared and realized in the new world. In contrast, there were some instincts could not be realized in the new world, yet possible for realization in the old world.
\end{abstract}

Keywords: old world, new world, between world, instinct

\begin{abstract}
Abstrak
Tokoh Hasan berada dalam posisi tarik-menarik antara dunia lama dan dunia baru. Dengan kata lain, Hasan berada di dunia "antara", antara dunia lama dan dunia baru. Dunia tersebut menjadikan Hasan bergumul dengan kebimbangan. Kebimbangan tersebut dibongkar menggunakan identifikasi struktur kepribadian psikoanalisis Sigmund Freud. Pengidentifikasian tersebut lebih difokuskan beberapa insting yang terdapat pada tataran $i d$. Insting kasih sayang, penghargaan, dan kebebasan yang ingin direalisasikan dibenturkan dengan pertimbangan-pertimbangan yang ada pada tataran ego maupun superego. Pertimbangan-pertimbangan tersebut memunculkan pengaktualisasian insting yang tidak dapat direalisasikan dalam dunia lama, tetapi dimunculkan kembali dan direalisasikan dalam dunia baru. Sebaliknya, terdapat pula insting yang tak dapat direalisasikan dalam dunia baru, tetapi memungkinkan untuk direalisasikan dalam dunia lama.
\end{abstract}

Kata kunci: dunia lama, dunia baru, dunia antara, insting

\section{Pendahuluan}

Hasan merupakan tokoh utama dari roman yang ditulis oleh salah seorang sastrawan kebanggaan Indonesia, Achdiat Karta Mihardja. Dikategorikan sebagai tokoh utama tentu dikarenakan perannya yang demikian penting dan utama dalam membentuk alur cerita. Oleh karena itu, tidak mengherankan jika di dalam diri tokoh utama inilah pengarang menitipkan pesan yang ingin disampaikannya. Pesan yang dihasilkan dari sebuah kontemplasi panjang dari rangkaian peristiwa kehidupan yang dijalaninya.

Santoso (2008) menyebutkan bahwa tokoh Hasan berada di antara dua dunia, yakni dunia lama dan dunia baru. Dunia lama diwakili kelompok masyarakat yang 
menganut paham tradisional dengan pola pikir kosmosentris, taat beribadah kepada Tuhan, dan sangat religius. Kelompok ini adalah lingkungan keluarga Hasan atau keluarga Raden Wiradikarta beserta orangorang yang berada di dekatnya. Sementara itu, dunia baru diwakili oleh sekelompok masyarakat yang menganut paham kebudayaan modern dengan pola pikir antroposentris, agresif, dan atheis. Kelompok ini terdiri atas teman-teman Hasan, yakni Rusli dan kawan-kawan.

Hasan sebagai tokoh utama dalam roman ini berada pada dua dunia tersebut. Keberadaannya pada dua dunia yang pada hal-hal tertentu sangat berseberangan telah memosisikan Hasan pada pertentanganpertentangan antara mengikuti pandangan dunia lama atau dunia baru. Berada di antara dua pandangan yang berbeda ini menjadikan Hasan selalu berada dalam kebimbangan. Keberadaannya yang tidak sepenuhnya berada pada dunia baru maupun dunia lama, penulis istilahkan dengan "dunia antara". Keberadaannya pada posisi itu menyebabkan terjadinya benturan-benturan sehingga memunculkan berbagai kegelisahan. Kegelisahan-kegelisahan itulah yang coba diuraikan dalam tulisan ini.

Berkaitan dengan psikologi tokoh, tulisan ini mencoba melakukan penganalisisan dengan menerapkan teori psikoanalisis Sigmund Freud. Secara umum, Freud melihat besarnya peranan alam bawah sadar yang mendasari perilaku maupun tindakan manusia dalam kehidupan seharihari. Alam bawah sadar tersebut merupakan manifestasi dari keinginan-keinginan terpendam yang tidak bisa direalisasikan.

\section{Kerangka Teori}

Psikoanalisis Freud yang dikenal dengan istilah teori mimpi ini merumuskan kepribadian manusia dalam tiga struktur yang terkait satu sama lain, yakni $i d$, ego, dan superego. Id bekerja berdasarkan prinsip kenikmatan, ego berdasarkan prinsip kenyataan, dan superego berdasar pada prinsip aturan atau norma (Milner, 1980). Sejalan dengan itu, Endaswara (2009) juga memaparkan bahwa id merupakan wadah dari naluri-naluri primitif yang menuntut pemuasan selekasnya. Ego yang merupakan wadah bagi rasio dan akal sehat senantiasa menjaga kestabilan manusia dan bersifat adaptif (bisa menyesuaikan diri) terhadap kenyataan. Sementara itu, superego merupakan wadah dari suara hati dan moral yang keduanya diturunkan dari masyarakat, khususnya dari sosialisasi dan ajaran atau didikan orang tua. Ketiga unsur kepribadian yang masing-masing bekerja berdasarkan prinsip kenikmatan, kenyataan, dan norma tersebut merupakan satu rangkaian yang selalu hadir dan tarik-menarik dalam diri seseorang ketika akan melakukan setiap tindakan atau perbuatan.

Kajian yang melihat sisi psikologis tokoh Hasan dengan berpatokan pada psikoanalisis Freud sebenarnya sudah dilakukan Bahri (2003). Akan tetapi, kajian tersebut belum memberikan penggambaran yang jelas dalam kaitannya dengan persinggungan psikologis tokoh. Hal itu dikarenakan adanya orientasi kajian yang lebih banyak memfokuskan pada keterkaitan psikologis tokoh tersebut dengan kebimbangan masyarakat era reformasi. Oleh karena itu, tulisan ini mencoba mengisi kekurangan tersebut.

\section{Metode Penelitian}

Tarik-menarik yang memunculkan kegelisahan-kegelisahan dalam diri Hasan sebagai konsekuensi dari posisinya yang berada di antara dua dunia tersebut akan coba dianalisis berdasarkan tiga struktur kepribadian sebagaimana digolongkan Freud. Penganalisisan tersebut diawali dengan pengidentifikasian keberadaan insting yang ada dalam diri Hasan. Dari insting-insting inilah kemudian akan dikaji 
lebih jauh tentang persinggungan psikologis Hasan ketika berada di dunia antara. Persinggungan-persinggungan tersebut merupakan pertimbangan-pertimbangan yang melatarbelakangi Hasan dalam mengambil keputusan.

\section{Pembahasan}

\subsection{Hasan dan Lingkungannya}

Sebagaimana telah dipaparkan sebelumnya, Hasan berada di antara dua dunia. Dua dunia tersebut berkaitan dengan lingkungan yang bisa dikatakan berbeda satu sama lain. Yang dikatakan sebagai lingkungan termasuk orang-orang yang berada di sekitarnya. Perbedaan inilah yang memosisikan Hasan berada dalam sebuah ruang yang "tidak jelas" atau bisa diistilahkan dengan dunia antara.

\subsubsection{Dunia Lama}

Dunia lama tokoh Hasan merupakan dunia yang masih belum dipengaruhi oleh pemikiran-pemikiran yang menimbulkan adanya kegelisahan-kegelisahan. Dunia ini bisa dikatakan sebagai peletak dasar yang memengaruhi sikap dan perilaku Hasan. Dalam lingkungan ini terjadi dukungmendukung antara perilaku dan lingkungan.

Dunia lama digambarkan dengan tokoh Hasan yang tinggal di sebuah kampung bernama Panyeredan. Kampung tersebut berlokasi di lereng Gunung Telaga Bodas.

"Di lereng gunung Telaga Bodas di tengah-tengah pergunungan Periangan yang indah, terletak sebuah kampung, bersembunyi di balik hijau pohon-pohon jeruk Garut, yang segar dan subur tumbuhnya berkat tanah dan hawa yang nyaman dan sejuk. Kampung Panyeredan namanya." (Mihardja, 1997:16)

Gambaran lokasi yang menjadi tempat tinggal Tokoh Hasan di atas merupakan lokasi yang jauh dari keramaian. Lokasi seperti ini memperkecil adanya pandangan- pandangan yang berbeda mengenai satu hal. Dengan kata lain, kecenderungan untuk berpandangan dan berpikiran seragam dalam lokasi seperti ini memiliki peluang yang lebih besar dibandingkan dengan pemikiran yang beragam. Dalam lingkungan seperti ini keinginan atau pandangan pribadi lebih sering dilebur atau disatukan dengan keinginan atau pandangan yang berlaku dalam masyarakat.

Di kampung tersebut Hasan tinggal di sebuah rumah batu bersama kedua orang tua dan saudara angkatnya. Orang tua Hasan bernama Raden Wiradikarta. Beliau adalah seorang alim dan taat menjalankan agama. Baginya tak ada perbuatan yang lebih baik selain ibadah. Guna lebih mendekatkan diri pada Tuhan, Raden Wiradikarta dan istrinya mengikuti ajaran tarikat (sufi) berkat anjuran Haji Dahlan.

Perilaku Hasan dalam kehidupan sehari-hari tidak jauh berbeda dengan perilaku sosok orang tua. Sejak kecil ia sudah dididik untuk mengerjakan sholat, menghafal surat-surat pendek, dan masih banyak lagi kegiatan-kegiatan keagamaan yang lain. Menjelang tidur, Hasan juga ditemani dengan cerita-cerita tentang surga dan neraka.

"Sebelum tidur, ibuku sudah biasa menyuruh aku menghafal ayat-ayat atau surat-surat dari Alquran. Sahadat, selawat dan kulhu, begitu juga fatihah aku sudah hafal dari masa itu. Juga nyanyi puji-puji kepada Tuhan dan Nabi." (Mihardja, 1997:21)

Perilaku seperti itu diberi ganjaran yang positif oleh lingkungan yang ada pada dunia lama. Ganjaran positif tersebut berupa penerimaan dan pujian yang memberikan rasa nyaman pada diri Hasan.

Pada usia remaja Hasan jatuh cinta dengan seorang gadis bernama Rukmini. Perasaan cocok mendorong Hasan untuk bertekad melanggengkan hubungan mereka sampai jenjang pernikahan. Akan tetapi, 
kedua orang tua mereka (Hasan dan Rukmini) masing-masing tidak menyetujui hubungan tersebut. Orang tua Hasan sebagai golongan bangsawan tidak ingin bermenantukan orang yang nonbangsawan. Pun sebaliknya, orang tua Rukmini tidak mau anaknya menikah dengan anak bangsawan.

Rukmini akhirnya dinikahkan dengan seorang laki-laki pilihan orang tuanya. Mengetahui hal tersebut Hasan pun diliputi kekecewaan. Ia mencoba menenangkan diri dengan mengikuti ajaran tarikat (sufi) seperti kedua orang tuanya. Di sisi lain, keikutsertaan Hasan dalam ajaran tarikat (sufi), tanpa suruhan, telah menumbuhkan kebahagian dan kebanggaan orang tuanya.

"Nah, anakku, syukurlah engkau sudah ada niat yang begitu suci. Sesungguhnya dengan niatmu yang suci itu, telah hilanglah segala kekuatiran yang selama ini kadang-kadang suka menekan dalam hatiku, ialah kekuatiran kalau-kalau dalam menempuh jalan hidup yang penuh dengan godaan dan bencana ini engkau akan tidak tahan, oleh karena engkau belum mempunyai senjata yang kuat." (Mihardja, 1997:25)

Setelah belajar dan mengikuti ajaran tarikat, Hasan semakin kuat menjalankan amalan-amalan dan ibadah sampai terkadang tanpa menghiraukan kesehatannya. Lama kelamaan, badannya pun mulai kurus dan yang lebih parah, ia terkena penyakit TBC.

Rangkaian peristiwa dan lingkungan sebagaimana telah dipaparkan di atas merupakan dunia yang dikategorikan sebagai dunia lama. Jika kita perhatikan lebih mendalam, dalam dunia tersebut perilaku Hasan selalu mengacu pada lingkungan sekitarnya. Dalam lingkungan seperti itu tidak diterima adanya pertentangan-pertentangan. Oleh karena itu, pertentangan-pertentangan yang muncul dalam diri Hasan dileburkan dengan nilainilai yang diakui oleh lingkungan dan hal itu ternyata mengarah pada ketenangan. Model seperti itulah yang terus membekas dan memberikan pandangan bagi Hasan tentang cara menemukan ketenangan

\subsubsection{Dunia Baru}

Dunia baru diawali dengan pertemuan Hasan dengan Rusli yang notabene teman bermain waktu kecil. Pertemuan tersebut terjadi ketika Hasan telah mendapatkan pekerjaan di sebuah kantor pemerintah dan tinggal kota Bandung, sebuah kota yang jauh dari lingkungan tempat tinggal orang tuanya.

Rusli adalah seorang penganut ajaran komunis yang memiliki banyak pengalaman hidup. Bersama Rusli, seorang gadis bernama Kartini yang bagi Hasan memiliki kemiripan dengan Rukmini. Hadirnya Kartini seolah membuka kenangan Hasan yang sudah lama tersimpan.

"Maka seakan-akan suatu "pembuka" dari Tuhan, insyaflah aku, bahwa Kartini itu sangat sama rupanya dengan Rukmini, bahwa mungkin karena itulah, maka aku merasa tertarik kepada Kartini itu." (Mihardja, 1997:46)

Sosok Kartini memberikan peranan yang besar terhadap perubahan diri dan perilaku Hasan. Pertentangan-pertentangan yang muncul akibat adanya pandangan yang berbeda terhadap suatu hal seringkali diabaikan. Pengaruh Kartini yang demikian kuat menjadikan Hasan mencoba berdamai dengan pandangan-pandangan yang dianut oleh Rusli dan kawan-kawan.

Secara perlahan, Hasan pun terpengaruh dan mengikuti pikiran, ajaran, dan tingkah laku berdasarkan ajaran yang disusupkan Rusli. Pengaruh tersebut tambah kuat setelah hadirnya Anwar, seorang individualis anarkis yang juga menaruh hati pada Kartini. Rasa cemburu menjadikan Hasan terdorong untuk selalu menunjukkan kebaikan untuk menumbuhkan simpati Kartini. Kebaikan itu termasuk menjalankan ajaran-ajaran maupun perilaku-perilaku yang 
baginya akan membuat Kartini bahagia, salah satunya dengan mengikuti modelmodel pikiran dan perilaku Rusli dan kawan-kawan yang pada dasarnya merupakan ajaran dan perilaku yang juga dianut Kartini.

Jika kita coba bandingkan, dunia lama dan dunia baru memiliki karakteristik yang berbeda satu sama lain. Dunia lama mendidik Hasan dengan adanya satu pandangan terhadap permasalahan, tidak ada lain. Sementara itu, dunia baru memberikan beragam pandangan atau penilaian terhadap suatu permasalahan. Dalam kondisi ketidakjelasan posisi ingin dipilih oleh Hasan itulah yang menempatkannnya pada dunia antara.

\subsubsection{Dunia Antara}

Nama dunia antara yang diberikan penulis dimaknai sebagai dunia yang memosisikan Hasan pada kebimbangan untuk memilih antara dunia lama atau dunia baru. Kondisi seperti ini sebenarnya sudah dimulai ketika Hasan sudah berada pada dunia baru. Hal itu ditandai dengan pertentangan-pertentangan dalam diri Hasan ketika melihat sikap, pandangan maupun perilaku Rusli dan kawan-kawan.

"Biarpun sudah banyak perobahan padaku sejak berkenalan dengan Rusli dan Kartini, namun ketika mendengar ucapan Anwar itu aku tidak bisa mengekang perkataan "audzubillah" itu, sekalipun cuma dalam hati. Hatiku memberontak. Ingin berdebat dengan orang istimewa itu." (Mihardja, 1997:104)

Berbagai pertentangan yang melingkupi diri Hasan pada awalnya masih bisa didamaikan karena ia berada pada lingkungan yang didominasi oleh penganut pemikiran-pemikiran yang identik dengan dunia baru. Pendamaian dilakukan dengan "menerima sementara" pemikiran-pemikiran tersebut.
Adanya pertentangan pada dasarnya diakibatkan oleh ketidaktegasan atau ketidakyakinan Hasan dalam menentukan pemikiran atau ajaran yang harus diikuti. Akan tetapi, ketegasan tersebut dituntut ketika Hasan pulang ke lingkungan lama, yakni Panyederan bersama Anwar. Kondisi lingkungan yang religius mendorong Hasan untuk kembali melakukan ibadah di kampung tersebut. Akan tetapi, sosok Anwar sebagai pentolan lingkungan baru justru mengecam dan menyatakan Hasan sebagai orang yang tidak tetap pendirian.

"Dalam lingkungan pergaulan dengan Bung Rusli, Kartini dan kawan-kawan lain tidak pernah sembahyang. Tapi sekarang, dengan mendadak kau tiba-tiba menjadi orang alim. Menjadi saleh, oleh karena kau berada dalam lingkungan orang-orang alim. Mana pendirianmu?"

(Mihardja, 1997:136)

Dikatakan sebagai orang yang tidak berpendirian oleh saingannya dalam memperebutkan perhatian Kartini telah mendorong Hasan menggugah, mendebat, dan mempertanyakan berbagai ritual dan kepercayaan yang selama ini dijalankan oleh orang tuanya. Raden Wira sebagai penganut agama yang kuat sangat kaget dengan pemikiran-pemikiran Hasan yang bertentangan dengan ajaran yang kepercayaannya yang notabene pernah juga dianut Hasan.

Perdebatan tersebut pada dasarnya didorong oleh ketidakinginan Hasan untuk disaingi oleh Anwar. Secara psikologis terdapat perasaan malu dalam diri Hasan jika pernyataan yang dilontarkan Anwar tersebut disampaikan atau diceritakan kepada Kartini. Dalam kondisi terjepit seperti itu Anwar melakukan tindakan yang bisa menutupi kekhawatiran itu, yakni menggugat ajaran dan pemikiran yang dianut orang tuanya.

Keputusan melakukan gugatan tersebut sebagai suatu bentuk dorongan 
untuk menghindarkan diri dari keterjepitan dibuktikan dengan perasaan menyesal setelah kembali dari Panyeredan.

"Kini insyaflah aku, betapa tersayatsayatnya rasa hati ibu dan ayah oleh perkataan-perkataan tadi malam. Kini terasa benar olehku, betapa tidak bijaksananya aku bercekcok dengan ayah tadi malam. Sesungguhnya, serasa remuk jiwaku kini. Remuk, karena rasa sesal menyayat-nyayat, rasa sedih mengirisiris." (Mihardja, 1997:156)

Dalam kondisi gundah seperti itu, Kartini sebagai salah seorang yang identik dengan lingkungan baru mampu memberikan ketenangan pada diri Hasan. Kartini dan Hasan pun akhirnya mengikat diri dalam bingkai pernikahan.

Setelah beberapa lama (tiga bulan), rumah tangga mereka mulai goyah. Hal itu berawal dari datangnya surat Raden Wira yang tidak menyetujui perkawinan mereka. Berbagai alasan yang dikemukakan orang tua Hasan dalam surat tersebut telah menyinggung hati Kartini. Ditambah lagi dengan hadirnya sosok Fatimah yang notabene sebagai gadis yang disetujui Raden Wira sebagai istri Hasan.

Sejak saat itu, Kartini sering keluar rumah bersama Anwar. Sosok Anwar sebagai penyulut rasa cemburu sekaligus menjadi pendorong pertengkaran dengan orang tua, telah menumbuhkan berbagai prasangka dalam diri Hasan. Puncak prasangka dan kecemburuan itu berujung pada kemarahan Hasan yang diluapkan dengan menampar wajah Kartini. Mendapat perlakuan seperti itu, Kartini minggat dari rumah dan meninggalkan Hasan dalam kesendirian.

Dalam kondisi jiwa yang diliputi kegalauan, Hasan mendapatkan kesimpulan bahwa ketidaktenangan yang menghinggapinya diakibatkan oleh adanya ketidaksesuaian antara yang menurutnya seharusnya dilakukan dengan yang dilakukannya.
Simpulan tersebut menghasilkan keputusan untuk menemukan ketenangan dengan melakukan sesuatu yang seharusnya dilakukan. Hal itu dilakukan dengan berusaha mengunjungi Raden Wira, ayahnya, yang tengah sakit. Namun, sesampainya di sana, ia tidak mendapat sambutan yang diharapkan. Dalam hembusan nafas terakhirnya, Raden Wira justru mengusir Hasan dengan alasan tidak ingin disesatkan.

Pengusiran itu menimbulkan pukulan keras bagi Hasan. Ia menyadari telah melakukan kesalahan besar. Penyesalan itu telah memberikan berbagai pertimbangan pada diri Hasan untuk memutuskan jalan yang harus ditempuh. Jika dikaitkan dengan dunia lama dan dunia baru, pertimbangan tersebut telah mendorong Hasan untuk tidak lagi berada di dunia antara.

Berbagai perilaku Hasan sebagaimana dipaparkan di atas pada dasarnya merupakan wujud kebimbangan antara menyatukan diri pada dunia lama atau dunia baru. Ketika menyatukan diri pada dunia lama, dunia baru menggugat. Begitu pula sebaliknya, ketika menyatukan diri pada dunia baru, dunia lama tidak menerima. Kondisi seperti inilah yang memosisikan Hasan pada dunia antara.

\subsubsection{Kajian Psikologis Hasan}

Freud membagi struktur kepribadian manusia menjadi tiga, yakni id, ego, dan superego. Ketiga unsur ini merupakan satu kesatuan yang tak terpisahkan dalam diri manusia. Id memunculkan keinginankeinginan yang muncul sebagai sebuah insting dari manusia. Realisasi dari id dipengaruhi oleh pertimbanganpertimbangan yang berasal dari ego dan superego. Jika keinginan yang muncul dalam id tersebut tidak bisa direalisasikan karena ego dan superego tak mengizinkan, keinginan itulah yang ditekan dan pada 
saatnya akan dimunculkan dalam alam bawah sadar manusia.

Dalam diri Hasan terdapat beberapa keinginan yang dikategorikan masuk dalam $i d$. Keinginan-keinginan tersebut meliputi insting kasih-sayang, insting penghargaan, dan insting kebebasan. Insting-insting tersebut dihadapkan pada pertimbangan ego maupun superego yang berada pada dunia lama maupun dunia baru sehingga terkadang direalisasikan dan terkadang tidak direalisasikan. Upaya penentangan atau tidak dihiraukannya pertimbanganpertimbangan tersebut menimbulkan ketidaktenangan pada diri Hasan. Hal ini terkadang mendorong Hasan untuk melakukan tindakan-tindakan yang mengarah pada penyalahan diri sendiri.

\subsubsection{Insting Kasih Sayang}

Insting kasih-sayang meliputi dua hal, yakni keinginan untuk mendapatkan kasihsayang dari orang tua dan lawan jenis. Kasih-sayang dari orang tua dapat direalisasikan oleh Hasan setelah adanya persetujuan yang didapatkan dari ego maupun superego. Dalam pertimbangan dunia nyata, keinginan untuk dicintai oleh orang tua didukung oleh adanya sosok orang tua Hasan yang berdasarkan ajaran yang dianutnya juga mencintai dan memberikan curahan kasih-sayangnya kepada Hasan. Dengan kata lain, $i d$ berupa keinginan untuk dicintai oleh orang tua didukung oleh ego dengan wujud keberadaan sosok orang tua, serta dibenarkan oleh pertimbangan superego dengan berpatokan pada ajaran agama yang dianut.

Pemenuhan terhadap keinginan untuk dicintai tersebut tentunya harus dibarengi dengan perilaku-perilaku yang sesuai dengan pertimbangan-pertimbangan tersebut. Tokoh Hasan yang pada dasarnya tidak bisa lepas dari keinginan untuk dicintai orang tua mengabaikan beberapa pertimbangan yang berkaitan dengan nilai- nilai yang dianut orang tua. Pengabaian tersebut didorong oleh persentuhannya dengan dunia baru.

Tokoh Hasan yang sudah mengetahui pertimbangan-pertimbangan yang harus dipenuhi untuk mendapatkan pemenuhan terhadap kasih sayang orang tua justru melakukan tindakan-tindakan yang mengarah pada pengabaian pertimbanganpertimbangan tersebut. Konsekuensi yang harus diterima dari perilaku seperti itu adalah ketidaktenangan. Secara otomatis, kasih sayang terhadap orang tua pun sudah tidak dapat diterima lagi.

Tindakan pengabaian yang dilakukan Hasan pada dasarnya dilakukan karena menggunakan pertimbangan yang berbeda. Dalam kasus ini terdapat dua pertimbangan yang berbeda, yakni pertimbangan yang berpatokan pada nilai atau pertimbangan superego yang dianut dunia baru dan nilai yang dianut dunia lama. Kasih sayang orang tua berkesesuaian dengan pertimbangan superego yang ada pada dunia lama. Oleh karena itu, pertimbangan superego dari dunia lama harus dipergunakan Hasan jika ingin mendapatkan kasih sayang orang tua. Namun, dorongan kuat dunia baru disertai dorongan dari berbagai faktor telah mendorong Hasan mengambil keputusan untuk mempergunakan pertimbangan superego yang dianut dunia baru. Konsekuensi dari tindakan itu pun akhirnya diterima Hasan dari orang tuanya.

"Kalau begitu, baiklah kita berpisah jalan saja. Kau sudah mendapat jalan sendiri, ayah dan ibu pun sudah ada jalan sendiri. Jadi baiklah kita bernapsi-napsi saja menempuh jalan masing-masing." (Mihardja, 1997: 158)

"Janganlah engkau dekat-dekat kepadaku....janganlah kauganggu aku dalam imanku, agar mudah kutempuh perjalananku ke hadirat-Nya..." (Mihardja, 1997:216) 
Dua situasi yang berbeda, yakni mendapatkan dan tidak mendapatkan kasih sayang orang tua telah menuntut Hasan untuk melakukan perbandingan. Dalam kondisi seperti itu, Hasan mengakui bahwa kasih sayang orang tua merupakan sebuah kebutuhan yang tidak bisa ditinggalkan. Usaha untuk mengembalikan kembali kasih sayang tersebut ternyata tidak membuahkan hasil sehingga pelampiasan terhadap hal yang lain pun dilakukan. Pada akhirnya, Hasan melakukan pelampiasan dengan menyalahkan diri sendiri.

"Kamu telah berdosa! Ayahmu sampai mati, karena tak tertahan lagi penderitaannya memikirkan pendirianmu yang sesat! Kamu telah ingkar dari agamamu sendiri! Kamu telah pecat dari imanmu kepada Tuhan! Telah murtad! Kafir! Atheis!" (Mihardja, 1997:217)

Selain keinginan untuk disayangi oleh orang tua, insting kasih sayang juga mendorong untuk direalisasikan dalam bentuk keinginan untuk dikasihsayangi oleh lawan jenis. Objek yang bisa memenuhi kebutuhan kasih sayang Hasan menurut kategori id adalah sosok Rukmini. Berdasarkan pertimbangan superego dengan berpatokan pada kriteria pandangan yang diajarkan agama, Rukmini sangat sesuai menjadi objek pemenuhan insting tersebut. Namun, berdasarkan pertimbangan ego, keinginan tersebut tak memungkinkan untuk direalisasikan. Dalam kehidupan dunia nyata, orang tua Hasan tak menyetujui hubungan tersebut disebabkan adanya perbedaan status sosial, yakni status Rukmini yang tidak bangsawan.

Sebagai keinginan yang tak bisa direalisasikan, insting kasih sayang terhadap lawan jenis tersebut ditekan ke alam bawah sadar dan dimunculkan kembali ketika Hasan berada pada dunia baru dengan sasaran Kartini sebagai objek. Jika berpatokan ukuran pertimbangan superego pada dunia lama, sosok Kartini sebenarnya tidak berterima. Namun, ketidakberterimaan tersebut diabaikan, Hasan lebih memilih pertimbangan keberterimaan yang mengacu pada pertimbangan superego dunia baru. Oleh karenanya, ketika Hasan beralih pada ukuran yang mengacu dunia lama ketidaktenangan kemudian menghinggapi jiwa Hasan. Hal itu tergambar ketika Hasan menerima surat dari orang tuanya setelah menikah dengan Kartini. Ketidaktenangan yang diliputi perasaan tersebut terus berlanjut hingga Hasan menemui ajalnya.

Kondisi kejiwaan Hasan berkaitan dengan insting kasih sayang dalam kaitannya dengan tarik-menarik antara dunia lama dan dunia baru tergambar dalam tabel berikut.

\begin{tabular}{|c|c|c|c|c|c|}
\hline \multirow[t]{2}{*}{ No } & \multirow[t]{2}{*}{ Insting } & \multicolumn{2}{|c|}{ Dunia Lama } & \multicolumn{2}{|c|}{ Dunia Baru } \\
\hline & & Wujud & Pengaruh & Wujud & Pengaruh \\
\hline 1. & $\begin{array}{l}\text { Kasih } \\
\text { sayang } \\
\text { orang } \\
\text { tua }\end{array}$ & Direalisasikan & tenang & $\begin{array}{l}\text { tak } \\
\text { terealisasikan } \\
\text { (adanya } \\
\text { pertimbangan } \\
\text { superego dunia } \\
\text { lama yang } \\
\text { dilanggar) }\end{array}$ & tidak tenang \\
\hline
\end{tabular}




\begin{tabular}{|c|c|c|c|c|c|}
\hline 2. & $\begin{array}{l}\text { Kasih } \\
\text { sayang } \\
\text { lawan } \\
\text { jenis }\end{array}$ & $\begin{array}{l}\text { tak } \\
\text { terealisasikan } \\
\text { (ditekan ke } \\
\text { alam bawah } \\
\text { sadar) }\end{array}$ & tenang & terealisasikan & $\begin{array}{l}\text { tenang (jika } \\
\text { dikaitkan } \\
\text { dengan } \\
\text { pertimbangan } \\
\text { superego dunia } \\
\text { baru) dan tidak } \\
\text { tenang (jika } \\
\text { dikaitkan } \\
\text { dengan } \\
\text { pertimbangan } \\
\text { dunia baru) }\end{array}$ \\
\hline
\end{tabular}

\subsubsection{Insting Penghargaan}

Insting penghargaan merupakan insting yang muncul dari keinginan untuk dihargai oleh lingkungan atau orang lain. Ketika berada pada dunia lama, keinginan untuk dihargai dapat direalisasikan karena adanya persetujuan dari pertimbangan ego maupun superego. Pertimbangan dunia nyata memberikan dukungan yang begitu luas kepada Hasan untuk dihargai. Di lingkungan keluarga, ia merupakan anak tunggal sehingga segala keinginan dan harapannya selalu dipenuhi, terlebih lagi dengan sikapnya yang selalu menuruti keinginan dan harapan orang tuanya, terutama dalam kaitannya dengan pelaksanaan ajaran agama.

Di lingkungan masyarakat, keluarganya termasuk dalam kategori orang terpandang sehingga secara otomatis akan berimbas pada diri Hasan yang merupakan anak dari orang yang terpandang dalam masyarakat. Segala perilaku dan kelakuan Hasan selalu dijadikan sebagai contoh bagi anak-anak yang berada di lingkungannya.

"Dan kenalan-kenalan itu lantas memuji aku, "Bagus Den! Bagus! (dan kepada anaknya sendiri) Nah, lihat Idris Den Asan sudah pintar sembahyang! Kau mesti contoh dia! Jangan Cuma suka main kelerang saja! (kepada ayah) Kalau si Idris nakal saja, juragan! Tidak seperti Den Asan.” (Mihardja, 1997:22)

Pemenuhan perasaan dihargai tersebut mulai tergoyahkan ketika Hasan berada pada lingkungan yang mewakili dunia baru.
Ukuran-ukuran penghargaan yang dijadikan pedoman oleh Hasan ternyata tidak dijadikan sebagai pedoman oleh lingkungan dunia baru. Penghargaan pada dunia baru tidak berpatokan pada seberapa taat seseorang menjalankan agama, melainkan pada seberapa luas orang memiliki pemikiran-pemikiran yang mengarah pada kebebasan.

Dalam kondisi seperti itu, insting penghargaan yang ada dalam diri Hasan tak terealisasikan. Hal itu disebabkan adanya pertimbangan ego (dunia nyata) yang tak mendukung untuk pemenuhan insting tersebut. Ketidakterimaan ego juga didukung oleh superego yang mendasarkan diri pada pertimbangan nilai dan patokan penghargaan sebagaimana dipaparkan di atas.

Hasan yang sudah terbiasa dengan pemenuhan insting penghargaan, merasa tidak dihargai. Ia berusaha mengubah patokan penghargaan yang dianutnya dengan berusaha berperilaku dan bertindak sesuai dengan patokan yang dijadikan dasar oleh lingkungan dunia baru.

Hal yang menjadi permasalahan adalah adanya pertentangan antara patokan dunia lama dengan dunia baru. Patokan yang ada pada dunia lama, seperti menjalankan ibadah zikir lama setelah sholat, bertentangan dengan patokan dunia baru yang justru harus lebih banyak meluangkan waktu untuk berdebat dan berdiskusi tentang ajaran-ajaran yang sebagian besar bertentangan dengan dunia lama. 
Dua pertimbangan yang berbeda menuntut Hasan untuk menentukan sikap. Kedekatannnya pada kehidupan dunia baru telah mendorongnya untuk mendekatkan diri pada pertimbangan-pertimbangan dunia baru. Dengan begitu berarti perilakuperilaku atau aktivitas yang dilakukan dengan berpatokan pada dunia lama harus ditinggalkan.

"Sembahyang hanya kadang-kadang saja lagi kulakukan, yaitu apabila aku merasa terlalu berat tertimpa oleh tekanan kesedihan yang tak terpikul lagi oleh batinku. Puasa sama sekali sudah kupandang suatu perbuatan yang sesat. Dan tidak muntah-muntah atau merasa jijik lagi kalau makan-makan di restoran Cina." (Mihardja, 1997:128)

Dari kutipan di atas dapat kita lihat bahwa dorongan berupa keinginan untuk tetap dihargai telah mendorong Hasan untuk menyampingkan pertimbanganpertimbangan, terutama pertimbangan superego yang dijadikan pedoman pada dunia lama. Dorongan tersebut dikuatkan lagi oleh Kartini yang notabene sebagai pemenuh insting kasih sayang terhadap lawan jenis.

Keputusan Hasan untuk merapat pada pertimbangan dunia baru bukan hal yang mudah. Berbagai pertimbangan melingkupi pikiran Hasan. Upaya-upaya untuk menggiring Rusli dan kawan-kawan pada pemikiran dunia lama telah coba dilakukan Hasan, tetapi alasan-alasannya justru dikalahkan oleh alasan-alasan penganut dunia baru. Keyakinan yang awalnya begitu besar berubah menjadi perasaan rendah diri yang secara otomatis berpengaruh pada keputusan yang diambil Hasan.

"Entahlah mungkin karena Rusli begitu banyak bertanya-tanya, yang semuanya harus kujawab dengan menggelengkan kepala, maka pada akhirnya timbullah semacam perasaan kurang harga diriku terhadap dia." (Mihardja, 1997:72)

Pengingkaran pertimbangan superego yang sudah melekat dalam diri Hasan ternyata memunculkan keresahan ketika Hasan kembali berada pada lingkungan dunia lama, yakni ketika Hasan mengunjungi orang tuanya bersama sahabatnya, Anwar, yang merupakan simbol dari penganut pemikiran dunia baru. Simbol dunia lama (orang tua Hasan) dan dunia baru (Anwar) yang berada pada satu tempat itu memunculkan perang dalam diri Hasan. Hal itu mendorong Hasan untuk menentukan kiblat yang harus diikuti.

Kekuatan dunia baru ternyata telah mendorong Hasan untuk mengabaikan pertimbangan-pertimbangan superego yang dijadikan pedoman oleh dunia baru. Pengabaian itu semakin tragis dengan mengambil lokasi di Panyeredan yang merupakan simbol dari basis yang mendukung pandangan-pandangan dunia lama.

Pengabaian pada pertimbanganpertimbangan superego yang berpatokan pada pemikiran dunia lama tersebut ternyata menumbuhkan ketidaktenangan dalam diri Hasan. Ketidaktenangan tersebut memunculkan pemikiran-pemikiran yang mengarah pada tindakan-tindakan impulsif. Kondisi seperti itu diperparah lagi dengan perilaku orang-orang dekat Hasan sebagai simbol dunia baru yang mengarah pada perilaku tidak menghargai diri Hasan.

\subsubsection{Insting Kebebasan}

Insting kebebasan merupakan keinginan untuk bebas menentukan harapan tanpa harus dibebani dengan tekanantekanan yang datang dari luar. Ketika berada dalam lingkungan dunia lama, insting kebebasan ini lebih banyak ditekan dan tidak memungkinkan untuk dimunculkan. Salah satunya adalah kebebasan untuk menentukan pasangan hidup. Ketika Rukmini yang 
menurut penilaian Hasan sangat cocok untuk dijadikan sebagai pasangan hidup, lingkungan keluarga ternyata tidak mendukung.

Insting kebebasan tersebut
menemukan penyaluran ketika Hasan berada pada lingkungan dunia baru. Dunia baru yang identik dengan kebebasan telah mendorong Hasan untuk melampiaskan segala keinginan yang sebelumnya terpendam, terutama dalam kaitannya dengan keinginan untuk mengemukakan pendapat.

Lingkungan dunia lama telah memberikan berbagai aturan dalam kaitannya dengan pengemukaan pendapat. Aturan-aturan tersebut telah mengekang berbagai keinginan yang memungkinkan untuk dimunculkan. Keinginan-keinginan tersebut menuntut untuk dikeluarkan setelah Hasan berada pada lingkungan dunia baru. Puncak kemunculan keinginan yang telah ditekan ke alam bawah sadar tersebut terjadi ketika Hasan menegaskan keinginannya kepada ayahnya, Raden Wiradikarta.

"Sekarang saya sudah dewasa," kataku, "sudah cukup matang untuk mempunyai pendirian sendiri dalam soalsoal hidup. Ayah tidak boleh memaksamaksa lagi kepada saya dalam hal pendirian saya. Juga dalam pendirian saya terhadap agama." (Mihardja, 1997:157)

Sikap Hasan seperti itu dibenarkan oleh pertimbangan superego dalam lingkungan dunia baru, tetapi tak dibenarkan oleh superego dunia lama. Pengaruh aturanaturan dalam dunia lama yang telah tertanam dalam diri Hasan ternyata memunculkan ketidaktenangan dalam diri Hasan. Ketidaktenangan itu semakin menjadi ketika Raden Wiradikarta, ayah Hasan yang menjadi simbol dunia lama, tidak menginginkan kehadiran Hasan dalam detikdetik terakhir menghadapi sakaratul maut.

\section{Penutup}

Kebimbangan tokoh Hasan berawal dari tuntutan pemenuhan insting yang ada dalam dirinya. Insting dalam diri Hasan yang diidentifikasi sebagai id dalam struktur kepribadian telah dimunculkan dan ditekan berdasarkan pertimbangan ego dan superego. Adanya dua dunia, yakni dunia lama dan dunia baru, telah memunculkan pertimbangan yang berbeda dalam perealisasian insting tersebut. Pertimbangan yang berbeda tersebut telah memunculkan ketidaktenangan dan kegamangan pada diri Hasan dalam menentukan pilihan. Dari sekian banyak pertentangan-pertentangan yang dihadapi, pertentangan yang diakibatkan pengabaian pertimbangan dari superego dunia lama menumbuhkan ketidaktenangan yang demikian panjang menyelimuti diri Hasan.

\section{Daftar Pustaka}

Bahri, Syaiful. (2003). “Aspek Psikoanalisis Sigmund Freud Tokoh Hasan dalam Roman Atheis Karya Achdiat K. Mihardja Serta Relevansinya dengan Kebimbangan Masyarakat Era Reformasi". (Skripsi tidak diterbitkan) Mataram: FKIP Unram.

Endaswara, Suwardi. (2009). Metode Penelitian Folklor: Konsep, Teori, dan Aplikasi. Yogyakarta: Media Presindo.

Mihardja, Achdiat K. (1997). Atheis. Jakarta: Balai Pustaka.

Milner, Max. (1980). Freud dan Interpretasi Sastra. (Apsanti Ds. dkk., penerjemah). Jakarta: Intermasa. (Karya asli diterbitkan 1992).

Santosa, Puji. (2008). "Benturan Dua Dunia" dalam Kaki Langit Horison. Jakarta: Horison. 